\title{
Antibacterial and Antifungal Evaluation of Chloroflavones
}

\author{
A. Rahim*, M. M. H. Bhuiyan, M. M. Matin and M. R. Alam \\ Department of Chemistry, University of Chittagong, Chittagong 4331, Bangladesh \\ Received 25 September 2017, accepted in final revised form 12 December 2017
}

\begin{abstract}
Two chloroflavones, $\mathbf{6}$ and $\mathbf{7}$ along with their corresponding chalcones, $\mathbf{4}$ and $\mathbf{5}$ have been tested for antibacterial and antifungal activities against six human pathogenic bacteria viz. Bacillus cereus (G+), Staphylococcus aureus (G+), Escherichia coli (G-), Vibrio choloriae (G-), Pseudomonas aeruginosa (G-), and Salmonella typhi (G-), and four plant as well as mold fungi viz. Aspergillus flavus, Aspergillus ochraceus, Aspergillus niger and Rhizopus spp.. The antibacterial and antifungal screens of the synthesized compounds were performed in vitro by the filter paper disc diffusion method and the poisoned food technique, respectively. The minimum inhibitory concentration (MIC) and minimum bactericidal concentration (MBC) of these synthesized compounds in comparison to ampicillin were also determined by broth micro-dilution method. Some of them were found to possess significant activity, when compared to standard drugs.
\end{abstract}

Keywords: Antibacterial activity; Antifungal activity; MBC; MIC; Flavones.

(C) 2018 JSR Publications. ISSN: 2070-0237 (Print); 2070-0245 (Online). All rights reserved. doi: http://dx.doi.org/10.3329/jsr.v10i1.33858 J. Sci. Res. 10 (1), $67-76$ (2018)

\section{Introduction}

The flavonoid compounds are a group of natural products widely occurring in natural plant pigments and medicinal plants [1,2]. They are found in fruits, vegetables, nuts, seeds and flowers as well as in teas and wines and are important constituent of human diet [3]. These products have been demonstrated to possess many biological and pharmacological activities such as antioxidant [4], anti-inflammatory [5], antimutagenic, antiallergic activities, and inhibitory activities on several enzymes [6,7]. Synthesis of these compounds has attracted considerable attention for their significant biocidal [8] and pharmaceutical $[9,10]$ effects. Because of the exciting biological activities, many flavonoid compounds have been synthesized and studied their antibacterial and antifungal activities [11,12]. Our previous articles [13,14] have also reported the antibacterial and antifungal effects of some flavonoids containing various groups in their ring system. Beneficial effects of flavonoids on human health have gained increasing interest among researchers over the last few years.

\footnotetext{
* Corresponding author: arahim7683@gmail.com
} 
Various strategies for the synthesis of flavone derivatives have been reported. The main synthetic methods known for flavones are oxidative cyclization [15,16] of 2'hydroxychalcones, the cyclodehydration [17] of 1-(2-hydroxyphenyl-3-phenyl-1,3propanedione) and via intermolecular Wittig reaction [18]. However, many of these methods suffered from harsh reaction conditions, toxic reagents, strong acidic / basic conditions, prolonged reaction time, poor yield and low selectivity. Recently, microwave irradiation has gained the attention of chemists for its unique advantages, such as shorter reaction times, cleaner reaction products, higher yields and better selectivity [19-21]. A survey of the literature provides information that chloroflavones 6 and $\mathbf{7}$ were synthesized under microwave irradiation [22] but their biological activities were not evaluated. So there is still a need for the evaluation of antibacterial and antifungal activities of these chloroflavones 6 and 7 compounds.

Encouraged by these observations and in continuation of search for antimicrobial active molecules [23-27], we are interested to synthesis as well as to evaluate the antibacterial and antifungal activities of the chloroflavones 6 and 7 along with their corresponding chalcones $\mathbf{4}$ and $\mathbf{5}$ in light of green protocol.

\section{Experimental}

\subsection{Materials and method}

Melting points were recorded with electro thermal melting point apparatus and were uncorrected. TLC was performed on Kieselgel $\mathrm{GF}_{254}$ and visualization was done by iodine vapour or UV light. The IR spectra were measured by FTIR spectrophotometer (Model8900, Shimadzu, Japan) using $\mathrm{KBr}$ matrix in the range 4000-200 $\mathrm{cm}^{-1} .{ }^{1} \mathrm{H}-\mathrm{NMR}$ (400 $\mathrm{MHz})$ and ${ }^{13} \mathrm{C}-\mathrm{NMR}(100 \mathrm{MHz})$ spectra were recorded on JEOL GS $\times 400$, GEOL JNMAL $400(400 \mathrm{MHz})$ and JEOL GS $\times 400$, GEOL JNMAL 400 (100 MHz) spectrometer with TMS as internal standard by using $\mathrm{CDCl}_{3}$ as solvent. All reactions were carried out in a commercially available LG microwave oven (MB-3947C) having a maximum power output of $800 \mathrm{~W}$ operating at $2450 \mathrm{MHz}$.

\subsection{Synthesis of 1-(2-hydroxyphenyl)-3-(chlorophenyl)-prop-2-en-1-one (2'-hydroxy- chlorochalcone) derivatives}

A mixture of $o$-hydroxyacetophenone and aromatic chloroaldehydes (1:1 mol) dissolved in minimum amount of rectified spirit and $\mathrm{KOH}(10 \%)$ were placed in an Erlenmeyer flask. The flask was covered with a funnel and then it was taken in a domestic microwave oven. The reaction mixture was irradiated under 320 watt microwave irradiation for 100$140 \mathrm{sec}$. The progress of the reactions was monitored by TLC ( $n$-hexane: ethyl acetate, 6:1) every $30 \mathrm{sec}$. The reaction mixture was cooled and diluted with ice cold water, acidified with dil. $\mathrm{HCl}$ and extracted with ether $(3 \times 15 \mathrm{~mL})$. The ether layer was washed with water and dried over anhydrous $\mathrm{Na}_{2} \mathrm{SO}_{4}$ and the solvent was evaporated under 
reduced pressure. The product was obtained as solid and recrystallized from ethyl acetate and $n$-hexane solvent mixture.

(E)-1-(2-hydroxyphenyl)-3-(2-chlorophenyl)-prop-2-en-1-one (2'-hydroxy-2-chlorochalcone), 4: Yellow crystals (yield: 99.63\%); m.p. 53-54 ${ }^{\circ} \mathrm{C}$; IR (KBr), $v_{\max }\left(\mathrm{cm}^{-1}\right): 3468(-$ $\mathrm{OH}), 3059,1639(>\mathrm{C}=\mathrm{O}), 1562(\mathrm{C}=\mathrm{C}), 1485(\mathrm{C}=\mathrm{C}, \mathrm{Ph}), 1257,1161,1026,829,756$. ${ }^{1} \mathrm{H}-\mathrm{NMR}\left(400 \mathrm{MHz}, \mathrm{CDCl}_{3}\right), \delta_{\mathrm{H}}(\mathrm{ppm}): 6.96$ (t, $\left.1 \mathrm{H}, J=8 \mathrm{~Hz}, \mathrm{C}_{5^{\prime}}-\mathrm{H}\right), 7.07$ (d, $1 \mathrm{H}, J=8 \mathrm{~Hz}$, $\left.\mathrm{C}_{3^{\prime}}-\mathrm{H}\right), 7.40\left(\mathrm{~d}, 2 \mathrm{H}, \mathrm{J}=8 \mathrm{~Hz}, \mathrm{C}_{4}-\mathrm{H}\right.$ and $\left.\mathrm{C}_{5}-\mathrm{H}\right), 7.52\left(\mathrm{~m}, 2 \mathrm{H}, \mathrm{C}_{3}-\mathrm{H}\right.$ and $\left.\mathrm{C}_{4^{\prime}}-\mathrm{H}\right), 7.67(\mathrm{~d}, 1 \mathrm{H}$, $\left.J=15.6 \mathrm{~Hz}, \mathrm{C}_{\alpha}-\mathrm{H}\right), 7.80\left(\mathrm{~d}, 1 \mathrm{H}, J=8 \mathrm{~Hz}, \mathrm{C}_{6}-\mathrm{H}\right), 7.93\left(\mathrm{~d}, 1 \mathrm{H}, J=8 \mathrm{~Hz}, \mathrm{C}_{6}-\mathrm{H}\right), 8.33(\mathrm{~d}, 1 \mathrm{H}$, $\left.J=15.6 \mathrm{~Hz}, \mathrm{C}_{\beta}-\mathrm{H}\right), 12.73\left(\mathrm{~s}, 1 \mathrm{H}, \mathrm{C}_{2^{2}}-\mathrm{OH}\right) .{ }^{13} \mathrm{C}-\mathrm{NMR}\left(100 \mathrm{MHz}, \mathrm{CDCl}_{3}\right), \delta_{\mathrm{C}}(\mathrm{ppm}): 117.2$ (C-3'), 121.2 (C-5'), 124.1 (C- $\alpha$ ), 124.6 (C-1'), 126.2 (C-5) 127.2 (C-6), 129.1 (C-3), 130.3 (C-4), 131.2 (C-6'), 132.2 (C-2), 135.6 (C-1), 137.3 (C-4'), 143.4 (C- $\beta$ ), 158.2 (C-2'), $186.1(>\mathrm{C}=\mathrm{O})$.

(E)-1-(2-hydroxyphenyl)-3-(4-chlorophenyl)-prop-2-en-1-one (2'-hydroxy-4-chlorochalcone), 5: Bright yellow crystals (yield: $98.64 \%)$; m.p. $148-149^{\circ} \mathrm{C}$; IR $(\mathrm{KBr}), v_{\max }\left(\mathrm{cm}^{-1}\right)$ : $3464(-\mathrm{OH}), 3066,1639(>\mathrm{C}=\mathrm{O}), 1581(\mathrm{C}=\mathrm{C}), 1485(\mathrm{C}=\mathrm{C}, \mathrm{Ph}), 1203,1153,1018,825$,

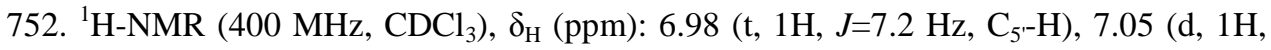
$\left.J=8 \mathrm{~Hz}, \mathrm{C}_{3^{\prime}}-\mathrm{H}\right), 7.44\left(\mathrm{~d}, 2 \mathrm{H}, J=8 \mathrm{~Hz}, \mathrm{C}_{3}-\mathrm{H}\right.$ and $\left.\mathrm{C}_{5}-\mathrm{H}\right), 7.54\left(\mathrm{~m}, 1 \mathrm{H}, \mathrm{C}_{4^{\prime}}-\mathrm{H}\right), 7.63(\mathrm{~d}, 2 \mathrm{H}$, $J=8 \mathrm{~Hz}, \mathrm{C}_{2}-\mathrm{H}$ and $\left.\mathrm{C}_{6}-\mathrm{H}\right), 7.65\left(\mathrm{~d}, 1 \mathrm{H}, J=16 \mathrm{~Hz}, \mathrm{C}_{\alpha}-\mathrm{H}\right), 7.93\left(\mathrm{~d}, 1 \mathrm{H}, J=16 \mathrm{~Hz}, \mathrm{C}_{\beta}-\mathrm{H}\right), 8.04$ $\left(\mathrm{d}, 1 \mathrm{H}, \quad J=8 \mathrm{~Hz}, \mathrm{C}_{6^{\prime}} \mathrm{H}\right), 12.76\left(\mathrm{~s}, 1 \mathrm{H}, \mathrm{C}_{2^{\prime}} \mathrm{OH}\right) .{ }^{13} \mathrm{C}-\mathrm{NMR}\left(100 \mathrm{MHz}, \mathrm{CDCl}_{3}\right), \delta_{\mathrm{C}}(\mathrm{ppm})$ : $117.2\left(\mathrm{C}-3^{\prime}\right), 122.1\left(\mathrm{C}-5^{\prime}\right), 123.6(\mathrm{C}-\alpha), 124.1\left(\mathrm{C}-1^{\prime}\right), 127.1$ (C-2 \& C-6), 128.6 (C-3 \& C5), 130.1 (C-6'), 133.2 (C-1), 133.5 (C-4), 137.1 (C-4'), 142.7 (C- $\beta$ ), 158.3 (C-2'), 186.3 $(>\mathrm{C}=\mathrm{O})$.

\subsection{Synthesis of 2-chlorophenyl-chromen-4-one (chloroflavone) derivatives}

1-(2-hydroxyphenyl)-3-(chlorophenyl)-prop-2-en-1-one derivatives (1 mmol) were suspended in (DMSO, $2 \mathrm{~mL}$ ) and placed in an Erlenmeyer flask and iodine $(0.02 \mathrm{mmol})$ was added. Then the covered flask was taken in the microwave oven. The mixture was irradiated under 320 watt microwave irradiation for 300-325 sec. The progress of the reactions was monitored by TLC ( $n$-hexane: ethyl acetate, $4: 1)$. The reaction mixture was diluted with water (excess), and extracted with diethyl ether $(2 \times 15 \mathrm{~mL})$. The ether layer was washed with aqueous $20 \%$ sodium thiosulphate, water and dried over anhydrous $\mathrm{Na}_{2} \mathrm{SO}_{4}$ and the solvent was evaporated. The product was obtained as solid crystals. The solid products were recrystallized using ethyl alcohol and it gave blue fluorescence in UV light.

2-(2-chlorophenyl)-chromen-4-one (2'-chloroflavone), 6: Pale yellow crystals (yield: 98.12\%), m.p. $118-119^{\circ} \mathrm{C}$; IR (KBr), $v_{\max }\left(\mathrm{cm}^{-1}\right): 3066,2981,2939,1639(>\mathrm{C}=\mathrm{O}), 1604$, $1573(\mathrm{C}=\mathrm{C}), 1465(\mathrm{C}=\mathrm{C}, \mathrm{Ph}), 1373,1222(\mathrm{C}-\mathrm{O}), 1091,1037,825,752 .{ }^{1} \mathrm{H}-\mathrm{NMR}(400$ $\left.\mathrm{MHz}, \mathrm{CDCl}_{3}\right), \delta_{\mathrm{H}}(\mathrm{ppm}): 6.86\left(\mathrm{~s}, 1 \mathrm{H}, \mathrm{C}_{3}-\mathrm{H}\right), 7.47\left(\mathrm{~d}, 1 \mathrm{H}, J=7.2 \mathrm{~Hz}, \mathrm{C}_{8}-\mathrm{H}\right), 7.73(\mathrm{~d}, 2 \mathrm{H}$, $\left.J=8 \mathrm{~Hz}, \mathrm{C}_{4^{\prime}}-\mathrm{H} \& \mathrm{C}_{5^{\prime}}-\mathrm{H}\right), 7.60\left(\mathrm{~d}, 1 \mathrm{H}, J=8.4 \mathrm{~Hz}, \mathrm{C}_{6}-\mathrm{H}\right), 7.74$ (t, 1H, J=8 Hz, C $\left.7-\mathrm{H}\right), 7.90$ (d, 
$\left.2 \mathrm{H}, J=8.4 \mathrm{~Hz}, \mathrm{C}_{3^{\prime}}-\mathrm{H} \& \mathrm{C}_{6^{\prime}} \mathrm{H}\right), \quad 8.26\left(\mathrm{~d}, 1 \mathrm{H}, J=7.2 \mathrm{~Hz}, \mathrm{C}_{5}-\mathrm{H}\right) .{ }^{13} \mathrm{C}-\mathrm{NMR}(100 \mathrm{MHz}$, $\mathrm{CDCl}_{3}$ ), $\delta_{\mathrm{C}}(\mathrm{ppm}): 97.3(\mathrm{C}-3), 118.2$ (C-8), 123.1 (C-6), 124.9 (C-4a), $126.9\left(\mathrm{C}-5^{\prime}\right), 127.1$ (C-6'), 128.7 (C-3'), 129.3 (C-4'), 130.2 (C-5), 131.2 (C-2'), 135.8 (C-7), 136.2 (C-1'), 158.3 (C-8a), $163.5(\mathrm{C}-2), 178.9(>\mathrm{C}=\mathrm{O})$.

2-(4-chlorophenyl)-chromen-4-one (4'-chloroflavone),7: Pale yellow crystals (yield: $97.41 \%)$, m.p. $185-186^{\circ} \mathrm{C}$; IR (KBr), $v_{\max }\left(\mathrm{cm}^{-1}\right): 3066,2924,2854,1654(>\mathrm{C}=\mathrm{O}), 1624$, $1573(\mathrm{C}=\mathrm{C}), 1469(\mathrm{C}=\mathrm{C}, \mathrm{Ph}), 1369,1219(\mathrm{C}-\mathrm{O}), 1126,1033,848,752 .{ }^{1} \mathrm{H}-\mathrm{NMR}(400$ $\left.\mathrm{MHz}, \mathrm{CDCl}_{3}\right), \delta_{\mathrm{H}}(\mathrm{ppm}): 6.68\left(\mathrm{~s}, 1 \mathrm{H}, \mathrm{C}_{3}-\mathrm{H}\right), 7.44\left(\mathrm{~m}, 3 \mathrm{H}, \mathrm{C}_{3^{\prime}}-\mathrm{H}, \mathrm{C}_{5^{\prime}}-\mathrm{H} \& \mathrm{C}_{8}-\mathrm{H}\right), 7.54(\mathrm{t}$, $\left.2 \mathrm{H}, \mathrm{J}=8.8 \mathrm{~Hz}, \mathrm{C}_{2^{\prime}}-\mathrm{H} \& \mathrm{C}_{6^{-}}-\mathrm{H}\right), 7.68\left(\mathrm{dd}, 1 \mathrm{H}, \mathrm{J}=7.2 \mathrm{~Hz}\right.$ and $\left.1.6 \mathrm{~Hz}, \mathrm{C}_{6}-\mathrm{H}\right), 7.73(\mathrm{t}, 1 \mathrm{H}$, $\left.\mathrm{J}=8.8 \mathrm{~Hz}, \mathrm{C}_{7}-\mathrm{H}\right), 8.28\left(\mathrm{dd}, 1 \mathrm{H}, \mathrm{J}=9.6 \mathrm{~Hz} \& \mathrm{~J}=1.6 \mathrm{~Hz}, \mathrm{C}_{5}-\mathrm{H}\right) .{ }^{13} \mathrm{C}-\mathrm{NMR}(100 \mathrm{MHz}$, $\left.\mathrm{CDCl}_{3}\right), \delta_{\mathrm{C}}(\mathrm{ppm}): 97.4(\mathrm{C}-3), 118.1(\mathrm{C}-8), 123.6(\mathrm{C}-6), 126.1(\mathrm{C}-4 \mathrm{a}), 127.1(\mathrm{C}-2$ ' \& C6'),127.9 (C-3' \& C-5'), 129.9 (C-5), 133.2 (C-1'), 133.3 (C-4'), 136.2 (C-7), 157.6 (C-8a), $167.7(\mathrm{C}-2), 178.3(>\mathrm{C}=\mathrm{O})$.

\subsection{Antimicrobial activities}

\subsubsection{Antibacterial screening}

The antibacterial activity of the synthesized compounds 4-7 were studied against six human pathogenic bacteria viz. Bacillus cereus (G+), Staphylococcus aureus (G+), Escherichia coli (G-), Vibrio choloriae (G-), Pseudomonas aeruginosa (G-), and Salmonella typhi (G-). For determination of this activity the filter paper disc diffusion method [28-29] was employed. Ampicillin was used as standard antibiotic for the antibacterial test. Nutrient agar (NA) was used as the basal medium for test bacteria. These agar media were inoculated with $0.5 \mathrm{~mL}$ of the $24 \mathrm{hr}$ liquid cultures containing $10^{7}$ micro-organisms $/ \mathrm{mL}$. The diffusion time was $24 \mathrm{hr}$ at $5^{\circ} \mathrm{C}$ and the incubation time was 12 $\mathrm{hr}$ at $37^{\circ} \mathrm{C}$ for bacteria. Discs with only DMSO were used as control. The diameter (in $\mathrm{mm}$ ) of the observed inhibition zones were taken as a measure of inhibitory activity.

\subsubsection{Determination of the Minimum Inhibitory Concentration (MIC) and Minimum Bactericidal Concentration (MBC)}

Minimum inhibitory concentrations (MICs) are defined as the lowest concentration of an antimicrobial that will inhibit the visible growth of a microorganism after overnight incubation and minimum bactericidal concentrations (MBCs) as the lowest concentration of an antimicrobial that will prevent the growth of an organism after subculture onto antibiotic-free media. The MICs are used by diagnostic laboratories mainly to confirm resistance, but most often as a research tool to determine the in vitro activity of new antimicrobials. The present study was performed to determine the MIC and MBC values of the synthesized compounds against six human pathogenic bacteria viz. Bacillus cereus (G+), Staphylococcus aureus (G+), Escherichia coli (G-), Vibrio choloriae (G-), Pseudomonas aeruginosa (G-), and Salmonella typhi (G-). The MIC and MBC of these 
tested compounds in comparison to ampicillin were determined against those selected bacteria by broth micro-dilution method [30]. The main advantage of the "micro dilution method" for the MIC determination lies in the fact that it can readily be converted to determine the $\mathrm{MBC}$ as well. The media used in this respect were nutrient broth. Dilution series were setup with $2,4,8,16,32,64,128,256,512$ and $1024 \mu \mathrm{g} / \mathrm{mL}$ of nutrient broth medium. To each well $100 \mu \mathrm{L}$ of standardized suspension of the testing bacteria $\left(10^{7}\right.$ cell $/ \mathrm{mL}$ ) were added and incubated at $30^{\circ} \mathrm{C}$ for $24 \mathrm{hr}$.

\subsubsection{Antifungal screening}

The antifungal activity of compounds 4-7 were evaluated towards four plant pathogenic and mold fungi, viz. Aspergillus flavus, Aspergillus ochraceus, Aspergillus niger and Rhizopus spp.. The antifungal activities of the synthesized compounds were assessed by poisoned-food technique [31]. Nystatin $(50 \mu \mathrm{g} / \mathrm{disc})$ was used as standard fungicide for the antifungal test. Potato Dextrose Agar (PDA) was used as basal medium for test fungi. The test chemicals $(100 \mu \mathrm{g})$ were mixed with sterilized potato dextrose agar (PDA) medium $\left(42^{\circ} \mathrm{C}\right)$ of the rate $100 \mathrm{mg} / \mathrm{mL}$ PDA. The medium was poured in sterilized petriplates. Inoculation was done by just touching the sample with the needle and then touching the needle at the middle of the plate containing solidified PDA media and then incubated at $27^{\circ} \mathrm{C}$ for 5 days. Radial growth of fungal colony was measured in mm after 3-5 days of incubation at $(25 \pm 2){ }^{\circ} \mathrm{C}$. A control set was maintained in each experimental using only PDA with DMSO as growth medium. The percentage inhibition of mycelial growth of the test fungi was calculated.

\section{Results and Discussion}

\subsection{Synthesis of 2-(chlorophenyl)-chromen-4-one (chloroflavone) derivatives}

The main aim of the present work involves the synthesis as well as antimicrobial activity of two derivatives of chloroflavones viz., 2'-chloroflavone 6, 4'-chloroflavone 7 . The synthesis of the above derivatives has been accomplished under microwave irradiation, as shown in Scheme 1. An important feature of this method is the survival of variety of functional group i.e. chloro group under the reaction conditions. The precursor chalcones, 4-5, were prepared from 2-hydroxyacetophenone and aromatic chloroaldehydes using literature procedure [32]. Alkaline condensation of 2-hydroxyacetophenone 1 with 2chlorobenzaldehyde $\mathbf{2}$ under microwave irradiation gave the corresponding 1-(2hydroxyphenyl)-3-(2-chlorophenyl)-1-prop-2-en-one 4 with very high yield (99.63\%). It was purified by recrystallization from $n$-hexane- ethyl acetate $(7: 1)$ mixture to obtain yellow crystals with m.p. $53-54^{\circ} \mathrm{C}$. The IR absorption band at $3468 \mathrm{~cm}^{-1}$ indicated the presence of hydroxyl group. A positive ferric chloride test also indicated that compound 4 has a free hydroxyl group and a band at $1639 \mathrm{~cm}^{-1}$ showed the presence of a conjugated carbonyl group $(>\mathrm{C}=\mathrm{O})$. 

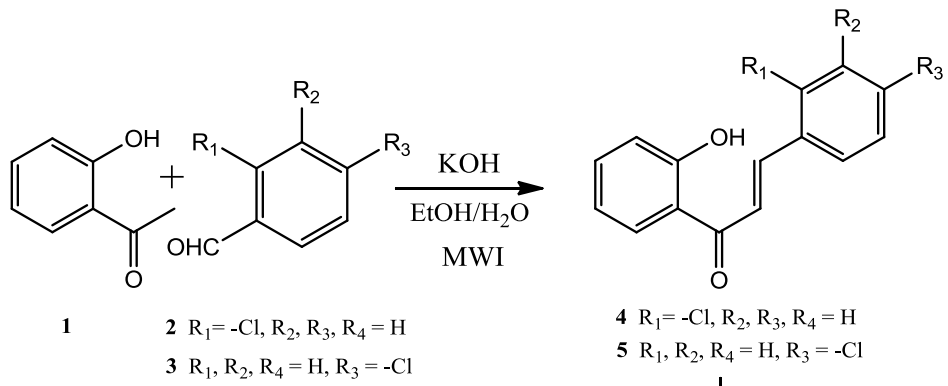

$$
\begin{aligned}
& 4 \mathrm{R}_{1}=-\mathrm{Cl}, \mathrm{R}_{2}, \mathrm{R}_{3}, \mathrm{R}_{4}=\mathrm{H} \\
& 5 \mathrm{R}_{1}, \mathrm{R}_{2}, \mathrm{R}_{4}=\mathrm{H}, \mathrm{R}_{3}=-\mathrm{Cl}
\end{aligned}
$$

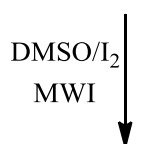

\section{Scheme I}

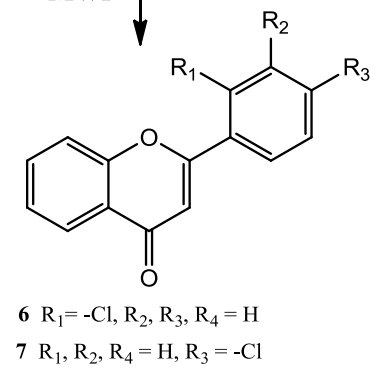

The ${ }^{1} \mathrm{H}$-NMR spectrum of 4 displayed a triplet signal resonated at $\delta_{\mathrm{H}} 6.96(\mathrm{~J}=8 \mathrm{~Hz})$ corresponding to one aromatic proton, $\mathrm{C}_{5}{ }^{\prime}-\mathrm{H}$ ortho to the carbonyl group. The presence of olefinic protons of an $\alpha, \beta$ unsaturated ketone which were clearly observed at $\delta 7.67$ $(J=15.6 \mathrm{~Hz})$ and $\delta 8.33(\mathrm{~J}=15.6 \mathrm{~Hz})$ corresponding to $\mathrm{C}_{\alpha}-\mathrm{H}$ and $\mathrm{C}_{\beta}-\mathrm{H}$, respectively. The higher coupling values show that the olefinic protons are in a trans- relationship. One doublet resonated at $\delta_{\mathrm{H}} 7.07(\mathrm{~J}=8 \mathrm{~Hz})$ corresponding to one aromatic proton, $\mathrm{C}_{3}{ }^{\prime}-\mathrm{H}$. The presence of two-proton doublet signal and two-proton multiplet resonated at $\delta_{\mathrm{H}} 7.40$ and $\delta_{\mathrm{H}} 7.52$ were designated to $\mathrm{C}_{4}-\mathrm{H}, \mathrm{C}_{5}-\mathrm{H}$, and $\mathrm{C}_{3}-\mathrm{H}, \mathrm{C}_{4}{ }^{\prime}-\mathrm{H}$, respectively. The two doublet signals at a lower field, $\delta_{\mathrm{H}} 7.80(\mathrm{~J}=8 \mathrm{~Hz})$ and $\delta_{\mathrm{H}} 7.93(\mathrm{~J}=8 \mathrm{~Hz})$ were attributed to two aromatic protons, $\mathrm{C}_{6}-\mathrm{H}$ and $\mathrm{C}_{6^{\prime}}-\mathrm{H}$, respectively. A characteristic singlet at $\delta 12.73$ indicated the presence of a chelated phenolic proton at $\mathrm{C}_{2^{\prime}}-\mathrm{OH}$ integrating for one proton. The ${ }^{13} \mathrm{C}$-NMR spectrum of compound 4 showed the presence of fifteen signals attributed to fifteen carbons corresponding molecular formula $\mathrm{C}_{15} \mathrm{H}_{11} \mathrm{O}_{2} \mathrm{Cl}$. The ${ }^{13} \mathrm{C}-\mathrm{NMR}$ spectrum showed the existence of a carbonyl group $(>\mathrm{C}=\mathrm{O})$ at $\delta$ 186.3. At the same time the olefinic carbon of $\mathrm{C}_{\alpha}$ and $\mathrm{C}_{\beta}$ resonated at $\delta 124.1$ and $\delta 143.4$, respectively. Remaining signals were assigned to the rest of the aromatic carbons in the molecule.

Oxidative cyclization of 1-(2-hydroxyphenyl)-3-(2-chlorophenyl)-prop-2-en-1-one 4 into the corresponding 2-(2-chlorophenyl)-chromen-4-one 6 was carried out using $\mathrm{DMSO} / \mathrm{I}_{2}$ reagent under microwave irradiation. It was purified by recrystallization from ethyl alcohol and obtained as light brown needles with a very good yield (98.12\%) and m.p. $118-119^{\circ} \mathrm{C}$. The formation of $\mathbf{4}$ has been supported by spectral data. The IR absorption at $1639 \mathrm{~cm}^{-1}$ showed the presence of a carbonyl group $(>\mathrm{C}=\mathrm{O})$ and the absence of a hydroxyl group band confirmed the oxidation of chalcone $\mathbf{4}$ into flavone 6 . Signal of 
$\mathrm{OH}$ was also not observed in ${ }^{1} \mathrm{H}-\mathrm{NMR}$ spectrum. The ${ }^{1} \mathrm{H}-\mathrm{NMR}$ spectrum of 6 also displayed a singlet resonated at $\delta_{\mathrm{H}} 6.86$ for one proton corresponding to $\mathrm{C}_{3}-\mathrm{H}$ and showed that the $\mathrm{C}_{\beta}-\mathrm{H}$ of the corresponding chalcone 4 involved in cyclization of chalcone to form corresponding flavone. The rest of the ${ }^{1} \mathrm{H}$ - and entire ${ }^{13} \mathrm{C}$-NMR spectral data were in accordance with the structure of 2-(2-chlorophenyl)-chromen-4-one 6 (see experimental section).

Similarly, the structures of the compounds $\mathbf{5}$ and $\mathbf{7}$ have been elucidated by IR, ${ }^{1} \mathrm{H}$ and ${ }^{13} \mathrm{C}$-NMR spectral data (see experimental).

\subsection{Antibacterial activity}

The antibacterial activity of compounds 4-7 has been assayed at concentrations of $100 \mu \mathrm{g}$ disc $^{-1}$ against strains of both, gram-positive and gram-negative pathogenic bacteria. Initially, susceptibility testing was carried out by measuring the inhibitory zone diameters on nutrient agar (NA), with conventional paper disc method and the inhibitory zone diameters were read and rounded off to the nearest whole numbers $(\mathrm{mm})$ for analysis. The inhibitory effects of compounds 4-7 against these organisms are given in Table 1. Some of the compounds showed low antibacterial activities and some were unable to show inhibition.

\subsection{Minimum Inhibitory Concentration (MIC) and Minimum Bactericidal Concentration $(\mathrm{MBC})$}

The minimum inhibitory concentration (MIC) and minimum bactericidal concentration (MBC) of compounds 4-7 in comparison to ampicillin against antibiotic susceptible strains of both gram-positive and gram-negative bacteria viz. Bacillus cereus (G+), Staphylococcus aureus (G+), Escherichia coli (G-), Vibrio choloriae (G-), Pseudomonas aeruginosa (G-) and Salmonella typhi (G-) were determined. Amongst all the compounds tested, 6 and 7 showed lower MIC values against both the gram-positive and gramnegative bacteria strains. The MBC of compounds 6 and 7 showed lower values and compounds $\mathbf{4}$ and $\mathbf{5}$ showed higher values for all bacteria strains. The MIC and MBC level of compounds 4-7 against these organisms are given in Tables 2 and 3, respectively.

\subsection{Antifungal activity}

The antifungal activity of compounds 4-7 has been assayed in vitro at a concentration of $100 \mu \mathrm{g} \mathrm{disc}{ }^{-1}$ against Aspergillus flavus, Aspergillus niger, Aspergillus ochraceus and Rhizopus spp.. The result of the percentage inhibitions of mycelial growth of the selected chemicals are presented in Table 4. The overall results of the present investigation showed that chloroflavones are somewhat effective than their corresponding chalcones towards the selected organisms (fungi). The effective inhibition or fungicidal effects of all the tested compounds are compared to the standard antibiotic Nystatin-50. 


\section{Antibacterial and Antifungal Evaluation of Cloroflavones}

Table 1. Inhibition against the two Gram-Positive and four Gram-Negative organisms by the compounds, 4-7.

\begin{tabular}{llllllc}
\hline \multirow{2}{*}{ Compd No. } & \multicolumn{6}{l}{ Diameter of zone of inhibition in $\mathrm{mm}(100 \mu \mathrm{g}(\mathrm{dw}) / \mathrm{disc})$} \\
\cline { 2 - 7 } & B. Cereus & S. Aureus & E. Coli & $\begin{array}{l}\text { Vibrio } \\
\text { Choloriae }\end{array}$ & $\begin{array}{l}\text { P. Aerugnosa } \\
\text { ( }\end{array}$ & $\begin{array}{c}\text { Salmonella } \\
\text { Typhi }\end{array}$ \\
\hline $\mathbf{4}$ & $\ldots$ & $\ldots$ & $* 10$ & $\ldots$ & $* 12$ & $* 12$ \\
$\mathbf{5}$ & $* 10$ & $* 10$ & $\ldots$ & 08 & 09 & $* 10$ \\
$\mathbf{6}$ & $* 10$ & $* 10$ & $* 11$ & 08 & $* 13$ & $* 14$ \\
$\mathbf{7}$ & $* 13$ & $* 13$ & $* 12$ & $* 10$ & $* 11$ & $* 10$ \\
AMP & 18 & 20 & 17 & 20 & 18 & 14 \\
\hline
\end{tabular}

N.B: '(...)’ Means no inhibition, ‘*’ Means good inhibition, dw.= dry weight.

Table 2. MIC level of tested compounds against the organisms by the test chemicals, 4-7.

\begin{tabular}{llllll}
\hline \multirow{2}{*}{ Test organism } & \multicolumn{5}{c}{ Minimum inhibitory concentration $\left(\mu \mathrm{g} \mathrm{mL}^{-1}\right)$ of compounds } \\
\cline { 2 - 6 } & $\mathbf{4}$ & $\mathbf{5}$ & $\mathbf{6}$ & $\mathbf{7}$ & AMP \\
\hline B. cereus & 128 & 128 & 32 & 64 & 4 \\
S. aureus & 128 & 64 & 64 & 32 & 4 \\
E. coli & 128 & 128 & 128 & 64 & 4 \\
Vibrio cholerae & 256 & 128 & 128 & 64 & 4 \\
P. aeruginosa & 128 & 128 & 32 & 128 & 8 \\
Salmonella typhi & 128 & 128 & 64 & 32 & 4 \\
\hline
\end{tabular}

Table 3. MBC level of tested compounds against the organisms by the test chemicals, 4-7.

\begin{tabular}{llllll}
\hline & \multicolumn{5}{c}{ Minimum bactericidal concentration $\left(\mu \mathrm{g} \mathrm{mL} \mathrm{mL}^{-1}\right)$ of compounds } \\
\cline { 2 - 6 } Test Organism & $\mathbf{4}$ & $\mathbf{5}$ & $\mathbf{6}$ & $\mathbf{7}$ & $\mathrm{AMP}$ \\
\hline B. cereus & $>256$ & 128 & 64 & 64 & 8 \\
S. aureus & 256 & 128 & 128 & 64 & 8 \\
E. coli & 256 & 128 & 128 & 64 & 8 \\
Vibrio cholerae & $>256$ & 256 & 128 & 128 & 8 \\
P. aeruginosa & 256 & 128 & 64 & 128 & 8 \\
Salmonella typhi & 256 & 256 & 64 & 64 & 8 \\
\hline
\end{tabular}

Table 4. Percent inhibitions of mycelial growth of fungi treated with different chemicals, 4-7.

\begin{tabular}{llllc}
\hline \multirow{2}{*}{ Compounds No. } & \multicolumn{4}{l}{ \% Inhibition of mycelial growth $(100 \mu \mathrm{g}(\mathrm{dw}) / \mathrm{ml}$ PDA $)$} \\
\cline { 2 - 5 } & A. flavus & A. niger & A. ochraceus & Rhizopus spp. \\
\hline $\mathbf{4}$ & 47 & 58 & 60 & 63 \\
$\mathbf{5}$ & 47 & 61 & 71 & 66 \\
$\mathbf{6}$ & 53 & 64 & 71 & 58 \\
$\mathbf{7}$ & 53 & 67 & 69 & 71 \\
Nystatin-50 & 53 & 61 & 66 & 68 \\
\hline
\end{tabular}




\section{Conclusion}

In this work, we have demonstrated the synthesis of chloroflavones using microwave irradiation. The advantages of this method are high yields, relatively short reaction times, low cost, simple experimental and isolation procedures, and finally, it is in agreement with the green chemistry protocols. From the result of antibacterial and antifungal activities, it can be concluded that the chloroflavones ring system and presence of chloro groups are responsible for the antimicrobial effects. The antimicrobial activity data obtained during the study will be certainly useful to go for further research for drug designing and synthesizing new flavone derivatives.

\section{Acknowledgments}

The authors are thankful to Dr. W. Shumi, Chairman, Department of Microbiology, University of Chittagong, Bangladesh for her cooperation in determining the antimicrobial activity of the synthesized compounds. The authors also wish to convey their special thanks to Professor Dr. Nurul Abser, Department of Chemistry, Jahangirnagar University, Bangladesh for recording ${ }^{1} \mathrm{H}-\mathrm{NMR}$ and ${ }^{13} \mathrm{C}-\mathrm{NMR}$ spectra.

\section{References}

1. C. Lu and C. Lin, Phytochem. 35, 781 (1994).https://doi.org/10.1016/S0031-9422(00)90605-8

2. Y. K. Rao, P. Harikishore, C. V. Rao, A.G. Blond, and B. Bodo, Phytochem. 61, 927 (2002). https://doi.org/10.1016/S0031-9422(02)00389-8

3. S. Alam, P. Satpathy, and A. Thosar, Int. Res. J. Pharm. 5(4), 244 (2014). https://doi.org/10.7897/2230-8407.050452

4. E. C. H. Chan, P. Patchareewan, and L.W. J. Owen, Cardiovasc. Pharmacol. 35, 326 (2000). https://doi.org/10.1097/00005344-200002000-00023

5. T. T. Dao, Y. S. Chi, J.Kim, H.P. Kim, S. Kim, and H. Park, Bioorg. Med. Chem. Lett. 14, 1165 (2004). https://doi.org/10.1016/j.bmcl.2003.12.087

6. W. Bors, W. Heller, C. Michel, M. Saran, In: Methods in Enzymology, L. Packer, A. N. Glazer (Eds.) (Academic Press, New York, USA, 1990). 186, pp. 343-355.

7. K. V. Rao, S. K. Chattopadhyay, and G. C. Reddy, J. Agric. Food Chem. 38, 1427 (1990). https://doi.org/10.1021/jf00095a023

8. A. M. Silva, M. Weidenborner, and J. A. S. Cavaleiro, Mycol. Res. 102, 638 (1998). https://doi.org/10.1017/S0953756297005480

9. J. N. Israelachvili, Intermolecular and Surface Forces, 2nd edition (Academic press, London, 1992).

10. R. Raturi, S. C. Sati, P. P. Badoni, H. Singh, and M. D. Sati, J. Sci. Res. 4(3), 769 (2012). https://doi.org/10.3329/jsr.v4i3.7725

11. S. Alam, Z. Sarkar, and A. Islam, J. Chem. Sci. 116, 29 (2004). https://doi.org/10.1007/BF02711433

12. S. Alam, M. A. J. Miah, and A. Islam, ACGC Chem. Res. Comm. 18, 1 (2005).

13. A. Rahim, R. Ali, and A. Islam, J. Sci. Res. 8, 209 (2016). https://doi.org/10.3329/jsr.v8i2.26622

14. R. Ali, A. Rahim, and A. Islam, J. Sci. Res. 9(3), 297 (2017). https://doi.org/10.3329/jsr.v9i3.31229

15. A. G. Doshi, P. A. Soni, and B. J. Ghiya, Indian J. Chem. 258, 759 (1986). 
16. Y. Hoshino, T. Ohinata, and N. Taken, Bull. Chem. Soc. 59, 2351 (1986). https://doi.org/10.1246/bcsj.59.2351

17. W. G.Kabalka and A. Mereddy, Tetrahedron Lett. 46(37), 6315 (2005). https://doi.org/10.1016/j.tetlet.2005.07.038

18. Y. L.Floc'h, and M. Lefeuvre, Tetrahedron Lett. 27(24), 2751 (1986). https://doi.org/10.1016/S0040-4039(00)84634-1

19. R. S. Varma, Green Chem. 1(1), 43 (1999). https://doi.org/10.1039/a808223e

20. B. L. Hayes, Microwave Synthesis, Chemistry at the Speed of Light., Matthews, NC (CEM Publishing, 2002).

21. B. Basu, P. Das, M. M. H. Bhuiyan, and S. Jha, Tetrahedron Lett. 44(19), 3817 (2003). https://doi.org/10.1016/S0040-4039(03)00731-7

22. M. J. Menezes, S. Manjrekar, V. Pai, R. E. Patre, and S. G. Tilve, Ind. J. Chem. 48B, 1311 (2009).

23. M. I. Hossain and M. M. H. Bhuiyan, J. Sci. Res. 1(1), 317 (2009). https://doi.org/10.3329/jsr.v1i2.2299

24. M. M. H. Bhuiyan and A. F. M. H. Rahman, J. Sci. Res. 3(1), 111 (2011). https://doi.org/10.3329/jsr.v3i1.5419

25. M. M. H. Bhuiyan, Hamidunnessa, and M. M. Mahmud, J. Sci. Res. 4(1), 143 (2012). https://doi.org/10.3329/jsr.v4i1.8688

26. M. M. H. Bhuiyan, M. I.Hossain, M. A. Alam, and M. M.Mahmud, Chem. J. 2(1), 67 (2012).

27. M. M. H. Bhuiyan, K. M. M. Rahman, M. A. Alam, and. M. M. Mahmud, Pak. J. Sci. Ind. Res. 56(3), 131 (2013).

28. H. Arima, H. Ashida, and G. I. Danno, Biosci. Biotechnol. Biochem. 66, 1009 (2002). https://doi.org/10.1271/bbb.66.1009

29. K. Jeongmok, R. M. Maurice, and I. W. J. Cheng, J. Agric. Food Chem. 43, 2839 (1995). https://doi.org/10.1021/jf00059a013

30. D. Amsterdam, V. I. Loman, Antibiotics in Laboratory Medicine, 4, 52 (1996).

31. R. K. Grover and J. D. Moore, Phytopathology 52, 876 (1962).

32. M. M. H. Bhuiyan, M. I. Hossain, M. M. Mahmud, M. Al-Amin, Chem. J. 1(1), 21 (2011). 